11. U.S. Health in International Perspective: Shorter Lives, Poorer Health. Washington, DC: National Research Council and Institute of Medicine of the National Academies; 2013.

12. OECD. Stat: Health Expenditure and Financing. https://stats.oecd. org/Index.aspx?DataSetCode=SHA. Accessed Apr 1, 2019.

13. Institute of Medicine. Graduate Medical Education That Meets the Nation's Health Needs. https://www.nap.edu/read/18754/chapter/1. Published 2014. Accessed Apr 1, 2019

14. The GME Initiative Medical Education for America's Health. https:// www.gmeinitiative.org/. Accessed Apr 1, 2019.

15. Bazemore A, Petterson S, Peterson LE, Phillips RL Jr. More comprehensive care among family physicians is associated with lower costs and fewer hospitalizations. Ann Fam Med. 2015;13(3):206-213.

16. Bazemore A, Petterson S, Peterson LE, Bruno R, Chung Y, Phillips $\mathrm{RL}$ Jr. Higher primary care physician continuity is associated with lower costs and hospitalizations. Ann Fam Med. 2018;16(6):492-497.

17. Basu S, Berkowitz SA, Phillips RL, Bitton A, Landon BE, Phillips RS. Association of primary care physician supply with population mortality in the United States, 2005-2015. https://jamanetwork-com. libproxy.lib.unc.edu/journals/jamainternalmedicine/fullarticle/27243 93?resultClick=1. Published 2018. Accessed Apr 1, 2019.

18. American Academy of Family Physicians. 2019 match results for family medicine. https://www.aafp.org/medical-school-residency/ program-directors/nrmp.html. Accessed March 29, 2019.

19. Moran MUS. Seniors matching to psychiatry increases for sixth straight year. https://psychnews.psychiatryonline.org/doi/full/10.1176/ appi.pn.2018.4a3. Published 2019. Accessed Apr 1, 2019.

20. National Family Medicine Residency Graduate Reports. https:// www.theabfm.org/research/national-family-medicine-residencygraduate-reports. Accessed Apr 1, 2019.

21. Coutinho AJ, Phillips RL Jr, Peterson LE. Intended vs reported scope of practice-reply. JAMA. 2016;315(20):2234-2235.

22. Tong ST, Hochheimer CJ, Barr WB, et al. Characteristics of graduating family medicine residents who intend to practice maternity care. Fam Med. 2018;50(5):345-352.

23. Weidner AKH, Phillips RL Jr, Fang B, Peterson LE. Burnout and scope of practice in new family physicians. Ann Fam Med. 2018;16(3):200-205.

\section{STFM FOUNDATION GIVES GRANTS TO 3 STFM COLLABORATIVES}

The STFM Project Fund encourages STFM Collaboratives and Special Project Teams to plan, develop, implement, evaluate, and disseminate findings from education-related scholarly projects. Awarded projects are expected to also provide students, residents, and new faculty an opportunity to participate in a significant way in a scholarly project that exposes them to STFM. This year, the STFM Foundation has chosen to provide $\$ 15,000$ in grants to the following projects.

\section{Project: Beginning Writing Skills for Early Career Minority Faculty}

This project is a 2-year extension of the writing workshops from STFM. The steering committee of the STFM Multicultural and Minority Health $(\mathrm{MMH})$ Collaborative will take on 6 new junior faculty members and actively mentor them from writing a letter to the editor to completing their first manuscript based on their published letter to the editor. Those faculty members will receive help in finding data sources, completing the IRB application, analyzing the data, and writing the manuscript.

"Writing skills for early career minority faculty are a must, not only to share work products from teaching, clinical and research missions, but also to support academic freedom and professional growth," said MMH Steering Committee member Kendall Campbell, MD, The Brody School of Medicine at East Carolina University.

The Collaborative was awarded $\$ 8,000$ for the project. "Without the generosity of the foundation, and the URM fund, it would've been impossible for us to be of service to our colleagues. Underrepresented minorities in medicine (URM) face multiple additional challenges to advancement in academic medicine when compared to their non-URM peers in all medical specialties including family medicine. We are delighted to offer this service to our colleagues to help them prepare for advancement and academic medicine," said the project's Principal Investigator Jose Rodriguez, MD, University of Utah Health Sciences.

The mentored faculty members will be encouraged to present at 2 conferences and use those presentations to inform the scholarly project.

\section{Project: Creation of a National Addiction Medicine Curriculum for Family Medicine Residency Programs}

The STFM's Addictions Collaborative was awarded $\$ 6,000$ over 2 years to create a national addiction medicine curriculum accessible to family medicine residency programs across the country seeking to launch a first-time curriculum or improve an existing one.

"This funding will help jumpstart efforts to develop national curriculum to train residents and faculty in addiction medicine. We hope the curricula and associated faculty development tools will fill a much-needed family medicine curricular void, helping physicians feel more competent and confident in treating patients who struggle with addiction while combating our current opioid epidemic," said the project's Principal Investigator Randi Sokol, MD, MPH, MMedEd, Tufts Family Medicine Residency, Malden, Massachusetts. 
The curriculum will be designed via a 3-step approach: (1) a list of core competencies will be developed by soliciting feedback from expert family medicine educators across the country and from national addiction societies' guidelines; $s_{i}$ (2) the curriculum will be developed based on these competencies $s_{i}(3)$ the curriculum will be tested and evaluated at several residency programs across the country before more broadly expanding access. The curriculum will cater to programs with various levels of need and include both online and in-person learning. High quality interactive modules with videos, case scenarios, knowledge checks, and learning objectives will be created that residents can complete asynchronously.

Taking a flipped classroom approach, an instructor's guide will be designed that faculty can use to facilitate an in-person classroom session with discussions and practice through case-based learning. Family medicine residency program faculty members will be offered opportunities for enhanced teaching support through a 6-month ECHO (Extension for Community Health Outcomes) hub that provides biweekly didactics, case presentations, and expert troubleshooting with members of the STFM Addictions Collaborative. This multimodal curriculum will provide a complete package of knowledge-based content and skill development that is adaptable to the needs and capacity of any residency program and specifically cater to faculty who have little specialized training in addiction but still create content that can be tweaked by those with more robust training.

Strategies will be designed for programs to support and evaluate resident competency development over time. The national addiction medicine curriculum will be piloted at several residency programs to evaluate its effectiveness and feasibility. The Collaborative plans to seek additional funding from national and state organizations to expand and improve the curriculum and disseminate it across the country. The principal Investigator for this project is Randi Sokol, MD, MPH, MMedEd, Tufts Family Medicine Residency, Malden, Massachusetts.

\section{Project: STFM/CFPC Global Family Medicine Education Symposium}

Many of the challenges faced in expanding and advocating for family medicine education are not unique to the United States context. Research and practice improvement findings are available from around the globe which can better inform US educational systems and structures and, similarly, allow the sharing of best practices with others. The STFM Global Health Educators Collaborative was awarded $\$ 1,000$ to host an evening dinner symposium on Monday, April 29 dur- ing the STFM Annual Spring Conference. The event, organized by STFM-GHEC leadership, in conjunction with colleagues in the College of Family Physicians of Canada, including representatives of the University of Toronto and the Besrour Center, offered an opportunity for both formal and informal networking and knowledge sharing between United States and internationally based physicians surrounding topics of key importance in family medicine education. The principal investigator for this project was Esther Johnston, MD, MPH, The Wright Center National Family Medicine Residency at HealthPoint, Auburn, Washington.

The STFM Project Fund chooses projects to fund that benefit members, the Society of Teachers of Family Medicine, and the discipline of family medicine.

Traci Brazelton, CAE

Director of Publications and Community Society of Teachers of Family Medicine

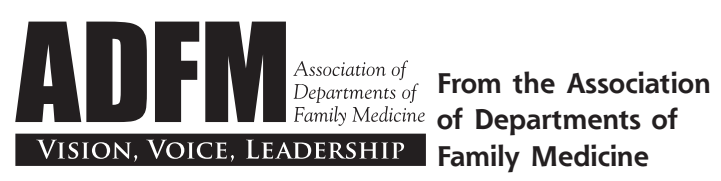

Ann Fam Med 2019;17:283-284. https://doi.org/10.1370/afm.2397.

\section{REBUILDING AFTER THE FLOOD: HIGHLIGHTS FROM THE 2019 ADFM WINTER MEETING}

In February, the Association of Departments of Family Medicine (ADFM) hosted another successful annual conference, this year in Houston, Texas. The theme of the meeting, "Rebuilding After the Flood: Designing Our Departments' Move Toward Value Based Health Care," was a nod to our meeting location as well as a concise summary of much of the conference content, which highlighted some of the tensions departments are facing in growing and changing to meet the needs of the current and future health care systems.

After a day of ever-popular preconference workshops, including one for the department administrators in ADFM and one on leadership focused on conflict engagement, we kicked off the conference with a bit of internal reflection. Our incoming president, Steve Zweig, MD, MSPH, gave a presidential address reflecting on how we are not alone on our individual or collective journeys, calling attention to who supports us along the way. Following this, Kevin Grumbach, MD, ADFM President, hosted an "interview" with Julie Moretz, Assistant Vice President for Patient- and Family-Centered Care and Chief Experience Officer at 